\title{
Improvement in the carcass traits and meat quality of growing-finishing Rongchang pigs by conjugated linoleic acid through altered gene expression of muscle fiber types
}

\author{
J.X. Huang ${ }^{1,2,3}$, R.L. Qi ${ }^{1,2,3}$, X.L. Chen ${ }^{4}$, X.Y. You ${ }^{1,2,3}$, X.Q. Liu ${ }^{1,2,3}$, \\ F.Y. Yang ${ }^{1,2,3}$ and Z.H. Liu ${ }^{1,2,3}$ \\ ${ }^{1}$ Chongqing Academy of Animal Science, Rongchang, Chongqing, China \\ ${ }^{2}$ Key Laboratory of Pig Industry Sciences, Ministry of Agriculture, \\ Rongchang, Chongqing, China \\ ${ }^{3}$ Chongqing Key Laboratory of Pig Industry Sciences, Rongchang, \\ Chongqing, China \\ ${ }^{4}$ Key Laboratory for Animal Disease-Resistance Nutrition of China Ministry \\ of Education, Institute of Animal Nutrition, Sichuan Agricultural University, \\ Yaan, Sichuan, China
}

Corresponding authors: Z.H. Liu

E-mail: liuzuohua66@163.com

Genet. Mol. Res. 13 (3): 7061-7069 (2014)

Received May 24, 2013

Accepted September 20, 2013

Published March 24, 2014

DOI http://dx.doi.org/10.4238/2014.March.24.25

ABSTRACT. A total of 160 Rongchang pigs $(26.76 \pm 1.78 \mathrm{~kg})$ were randomly assigned to 5 dietary treatment groups until their body weight $(\mathrm{BW})$ reached $90 \mathrm{~kg}$. The diets were supplemented with 0 , $0.5,1.0,1.5$, and $2.0 \%$ conjugated linoleic acid (CLA). Our results showed that the 1.0 to $2.0 \%$ CLA-fed pigs had less back fat deposition when their BW reached $90 \mathrm{~kg}$ than the pigs that received less than $1 \%$ CLA. During the 30 to $60 \mathrm{~kg}$ growing period, 1.0, 1.5, and 2.0\% CLA treatments improved pork quality by significantly reducing the pork $\mathrm{pH}(\mathrm{P}<0.01)$ and color value $(\mathrm{P}<0.05)$, but they increased marble 
scaling $(\mathrm{P}<0.01)$. Similarly, the 1.5 and $2.0 \%$ CLA-fed pigs had more marble than other pigs when their BW reached $90 \mathrm{~kg}$. Furthermore, CLA significantly affected the expression of muscle fiber-type genes. The $1.5 \%$ CLA-fed pigs exhibited the highest mRNA expression of $\mathrm{MyHC} 1$ and MyHC2a $(\mathrm{P}<0.05)$ at $60 \mathrm{~kg} \mathrm{BW}$. At $90 \mathrm{~kg} \mathrm{BW}$, the highest expression of MyHC1 and MyHC2a $(\mathrm{P}<0.05)$ was found in the $2.0 \%$ CLA group. However, MyHC2x was downregulated in the CLA-fed pigs at this time. In addition, CLA supplements did not evidently alter mRNA expression of MyHC2b at all times. These results demonstrate that CLA could affect carcass traits and improve the meat quality of growing-finishing pigs by altering the expression of genes related to muscle growth and development; $1-1.5 \%$ CLA was the most appropriate CLA dose.

Key words: Conjugated linoleic acid; Meat quality; Pig Muscle fiber; Gene expression

\section{INTRODUCTION}

Conjugated linoleic acid (CLA), containing conjugated double bonds, comprises 18 carbon fatty acids that exist as a mixture of positional and geometric (cis or trans) isomers of linoleic acid (18:2 n-6). CLA has been extensively studied because of its beneficial effects on humans and animals, such as decreased body fat accumulation (Belury, 2002). Although as many as 56 possible isomers exist, only 2 (cis-9, trans-11 and trans-10, cis-12) have received considerable attention because of their known biological effects (Hayashi et al., 2007).

Excellent meat quality is one of the most desirable traits of the Rongchang pig, which is indigenous to China. The intramuscular fat level in the Rongchang pig is almost thrice that of the European hybrid pigs (Lu et al., 2008). However, Rongchang pigs also have significantly higher back fat thickness than foreign breeds, which is unfavorable for pork production (Wang et al., 2011). Evidence has shown that CLA could reduce back fat thickness and increase intramuscular fat content in growing-finishing pigs (Thiel et al., 2001; Joo et al., 2002). In this study, we evaluated the overall effects of dietary CLA on growth performance, carcass traits, and pork quality as well as on the gene expression of growing-finishing Rongchang pigs. We also explored the optimal level of CLA in feeding.

\section{MATERIAL AND METHODS}

\section{Animals and diets}

A total of 160 Rongchang pigs (average body weight, $26.76 \pm 1.78 \mathrm{~kg}$ ) were randomly divided into 5 groups. Each group (32 pigs) was further randomly divided into 8 replicates of 4 pigs. Each group of pigs was fed a diet supplemented with 0, 0.5, 1.0, 1.5, and 2.0\% CLA (source containing $61.2 \%$ free CLA, Qingdao Aohai Company, China). The profile of CLA isomers was $28.5 \mathrm{~g} \mathrm{c} 9$, t11-CLA/100 g, $30 \mathrm{~g} \mathrm{t10}$, and c12-CLA/100 g. All diets were formulated to provide similar nutrition levels and according to the recommended nutritional needs 
for female pigs at certain ages ( 30 to 60 or 60 to $90 \mathrm{~kg}$ ) by the Chinese meat-fat type pig feeding standard (NY/T 95-2004) (Table 1). One pig from each replicate was randomly selected for slaughter with final weights of 60 and $90 \mathrm{~kg}$ per replicate.

Table 1. Composition of the basal diets for pigs at different periods (air-dry basis, \%).

\begin{tabular}{|c|c|c|c|c|c|}
\hline Ingredients & 30 to $60 \mathrm{~kg}$ & 60 to $90 \mathrm{~kg}$ & Nutrient levels ${ }^{b}$ & 30 to $60 \mathrm{~kg}$ & 60 to $90 \mathrm{~kg}$ \\
\hline Corn & 70.30 & 72.60 & $\mathrm{DE}(\mathrm{MJ} / \mathrm{kg})$ & 13.84 & 13.83 \\
\hline Soybean meal & 14.00 & 11.00 & $\mathrm{CP}(\%)^{\mathrm{b}}$ & 15.95 & 13.95 \\
\hline Wheat bran & 11.50 & 12.50 & $\mathrm{Ca}(\%)^{\mathrm{b}}$ & 0.72 & 0.61 \\
\hline Soybean oil & 2.00 & 2.00 & $\mathrm{TP}(\%)$ & 0.54 & 0.47 \\
\hline Limestone & 0.71 & 0.71 & $\mathrm{AP}(\%)$ & 0.29 & 0.22 \\
\hline Calcium hydrogen phosphate & 0.50 & 0.10 & DLys (\%) & 0.71 & 0.49 \\
\hline $\mathrm{NaCl}$ & 0.30 & 0.30 & DMet (\%) & 0.21 & 0.19 \\
\hline Lysine & 0.00 & 0.10 & DMet+DCys (\%) & 0.43 & 0.39 \\
\hline Premix $^{a}$ & 0.69 & 0.69 & DThr $(\%)$ & 0.43 & 0.37 \\
\hline \multirow[t]{2}{*}{ Total } & 100.00 & 100.00 & DTrp (\%) & 0.14 & 0.12 \\
\hline & & & DIle $(\%)$ & 0.49 & 0.40 \\
\hline
\end{tabular}

a Provided per kilogram of diet: $\mathrm{Cu}\left(\mathrm{CuSO}_{4} \cdot 5 \mathrm{H}_{2} \mathrm{O}\right) 80 \mathrm{mg}, \mathrm{Fe}\left(\mathrm{FeSO}_{4} \cdot 7 \mathrm{H}_{2} \mathrm{O}\right) 100 \mathrm{mg}, \mathrm{Zn}\left(\mathrm{ZnSO}_{4} \cdot 7 \mathrm{H}_{2} \mathrm{O}\right) 100 \mathrm{mg}$, $\mathrm{Mn}\left(\mathrm{MnSO}_{4} \cdot \mathrm{H}_{2} \mathrm{O}\right) 40 \mathrm{mg}$, Se $\left(\mathrm{Na}_{2} \mathrm{SeO}_{3}\right) 0.3 \mathrm{mg}$, I (KI) $0.3 \mathrm{mg}$, VA $1750 \mathrm{IU}, \mathrm{VD}_{3} 200 \mathrm{IU}, \mathrm{VE} 11 \mathrm{IU}, \mathrm{VK}_{3} 0.5 \mathrm{mg}$, niacin $20 \mathrm{mg}$, pantothenic acid $9 \mathrm{mg}$, folic acid $0.3 \mathrm{mg}, \mathrm{VB}_{1} 1 \mathrm{mg}, \mathrm{VB}_{2} 3 \mathrm{mg}, \mathrm{VB}_{6} 1.5 \mathrm{mg}, \mathrm{VB}_{12} 15 \mu \mathrm{g}$, biotin $0.05 \mathrm{mg}$, choline chloride $1.0 \mathrm{~g}$, phytase $0.1 \mathrm{mg}$, anti-oxidant $0.5 \mathrm{mg}$. ${ }^{\mathrm{b}}$ Measured value.

\section{Carcass traits}

Carcass traits and meat qualities were assessed in the left loin. The main detection indices include: carcass length, back fat depth between the 6th and 7th ribs, back fat depth at the 10th and last ribs, loin eye area, yield of carcass, leaf fat weight, and percentage lean content of the carcasses.

\section{Meat qualities}

The intramuscular fat (IMF) content of the longissimus dorsi muscle was determined using the Soxhlet extractor method. The shear force in the psoas and semitendinosus muscle was determined using a digital-display muscle tenderness determination device (C-LM3, Harbin, China). The water loss rate in the longissimus dorsi muscle between the 1st and 3rd lumbar vertebrae was measured using an unconfined pressure apparatus (WW-2A, Beijing, China). The longissimus dorsi muscle at the 6th and 10th thoracic vertebrae was removed for drip loss sampling.

The last 1-3 chest vertebrae of the longissimus muscle were selected for color, marble scaling, and $\mathrm{pH}$ value measurements. Tris-stimulus color coordinates, namely, lightness ( $\left.\mathrm{L}^{*}\right)$, redness $\left(\mathrm{a}^{*}\right)$, and yellowness $\left(\mathrm{b}^{*}\right)$, were recorded using a Chroma Meter (CR-400, Minolta, Osaka, Japan). The marble was measured according to marbling standards (National Pork Producers Council). Then, $\mathrm{pH} 1$ at 30 to $45 \mathrm{~min}$ and $\mathrm{pH} 224 \mathrm{~h}$ post-mortem were measured using SFK-Technology PH-STAR (DK-2730, Herlev, Denmark).

\section{mRNA expression of regulators of muscle fiber type}

The mRNA expression of some key factors in muscle fiber development ( $\mathrm{MyHC1}$, MyHC2a, MyHC2b, and MyHC2x) were measured using real-time polymerase chain reaction 
(PCR), as described previously (Qi et al., 2012). Real-time PCR was performed using an ABI 7300 system (ABI, USA) with a $20-\mu \mathrm{L}$ reaction mixture containing $10.0 \mu \mathrm{L}$ SYBR Premix Ex $\mathrm{Taq}^{\mathrm{TM}} \mathrm{II}$ (TaKaRa, Japan), $0.8 \mu \mathrm{L}$ forward primer, $0.8 \mu \mathrm{L}$ reverse primer, $2 \mu \mathrm{L}$ template cDNA, $0.4 \mu \mathrm{L}$ dye, and $6 \mu \mathrm{L} \mathrm{ddH}_{2} \mathrm{O}$. The cycling conditions comprised an initial single cycle of $30 \mathrm{~s}$ at $95^{\circ} \mathrm{C}$, followed by 40 cycles of $5 \mathrm{~s}$ at $95^{\circ} \mathrm{C}$ and $35 \mathrm{~s}$ at the melting temperature (Table 2). To correct for the differences in the amounts of template DNA, the mRNA level is shown as a ratio to the $\beta$-actin mRNA level.

\begin{tabular}{|c|c|c|}
\hline Gene & Primer sequences $\left(5^{\prime} \rightarrow 3^{\prime}\right)$ & $\operatorname{Tm}\left({ }^{\circ} \mathrm{C}\right)$ \\
\hline МуHC1 & $\begin{array}{l}\text { F: AAGGGCTTGAACGAGGAGTAGA } \\
\text { R: TTATTCTGCTTCCTCCAAAGGG }\end{array}$ & 58.2 \\
\hline MyHC2a & $\begin{array}{l}\text { F: GCTGAGCGAGCTGAAATCC } \\
\text { R: ACTGAGACACCAGAGCTTCT }\end{array}$ & 57.0 \\
\hline MyHC2b & $\begin{array}{l}\text { F: ATGAAGAGGAACCACATTA } \\
\text { R: TTATTGCCTCAGTAGCTTG }\end{array}$ & 55.6 \\
\hline MyHC2x & $\begin{array}{l}\text { F: AGAAGATCAACTGAGTGAACT } \\
\text { R: AGAGCTGAGAAACTAACGTG }\end{array}$ & 55.0 \\
\hline$\beta$-actin & $\begin{array}{l}\text { F: GCGGCATCCACGAAACTAC } \\
\text { R: TGATCTCCTTCTGCATCCTGTC }\end{array}$ & 56.3 \\
\hline
\end{tabular}

\section{Statistical analysis}

Data were analyzed using the GLM procedure of SAS 9.0 (SAS Inst. Inc., Cary, NC, USA). Group differences were analyzed by least significant difference, and the differences were considered to be significant at $\mathrm{P}<0.05$.

\section{RESULTS}

\section{Carcass traits}

The carcass traits of pigs at $60 \mathrm{~kg}$ are shown in Table 3. Most of the traits exhibited no evident changes among groups, and only the 1.0 and 1.5\% CLA-fed pigs exhibited a slight decrease in several traits, such as the vertical and incline lengths of the carcass and back fat depths at the shoulder-lumbar region between the 6th and 7th ribs as well as those at the 10th and last ribs. In addition, an increasing trend was observed on the loin eye area. Interestingly, the percentage lean content of the carcasses was remarkably increased in the 1.0, 1.5, and $2.0 \%$ CLA treatment groups $(\mathrm{P}<0.01)$.

The carcass traits of pigs at $90 \mathrm{~kg}$ are shown in Table 4 . We found that 1.0, 1.5, and $2.0 \%$ CLA significantly decreased back fat depth at the shoulder-lumbar region by 12.22 to $13.92 \%$ compared to that of the control. In addition, 1.0, 1.5, and 2.0\% CLA also significantly decreased the back fat depth between the 6th and 7th ribs by $21.84 \%(\mathrm{P}>0.05), 7.76 \%(\mathrm{P}>$ $0.05)$, and $15.80 \%(\mathrm{P}<0.01)$, respectively, compared to that of the control. Moreover, 1.0$2.0 \%$ CLA significantly decreased the skin-fat depth at the 10th rib by approximately 15.20 to $20.95 \%(\mathrm{P}<0.05)$. With increasing CLA level, a decreasing trend was observed on the fat-skin depth, but an increasing trend was found on the loin eye area. Similarly, 1.0 and 2.0\% CLA significantly increased the percentage lean content of the carcasses compared with the control, and no significant difference was found among the other groups $(\mathrm{P}>0.05)$. 
Table 3. Effects of different conjugated linoleic acid (CLA) levels on the carcass parameters of pigs at $60 \mathrm{~kg}$.

\begin{tabular}{|c|c|c|c|c|c|c|c|}
\hline Items & Control & $0.5 \%$ CLA & $1 \%$ CLA & $1.5 \%$ CLA & $2 \%$ CLA & SE & $\mathrm{P}$ value \\
\hline Body weight at slaughter $(\mathrm{kg})$ & 61.8 & 62.5 & 61.2 & 62.4 & 62.6 & 0.90 & 0.8151 \\
\hline Vertical length $(\mathrm{cm})$ & 78.5 & 80.1 & 80.0 & 81.2 & 78.8 & 1.13 & 0.4236 \\
\hline Incline length $(\mathrm{cm})$ & 67.9 & 68.5 & 69.7 & 69.4 & 67.1 & 1.13 & 0.5038 \\
\hline \multicolumn{8}{|l|}{ Back fat depth $(\mathrm{cm})$} \\
\hline Shoulder-lumbar region & 2.61 & 2.74 & 2.41 & 2.43 & 2.68 & 0.13 & 0.2800 \\
\hline Between the 6 th and 7 th ribs & 2.66 & 2.54 & 2.41 & 2.42 & 2.62 & 0.16 & 0.7484 \\
\hline \multicolumn{8}{|l|}{ Fat-skin depth $(\mathrm{cm})$} \\
\hline 10th rib & 2.68 & 2.65 & 2.51 & 2.30 & 2.48 & 0.17 & 0.5302 \\
\hline Last rib & 1.99 & 2.00 & 1.80 & 1.86 & 1.95 & 0.16 & 0.8885 \\
\hline Loin eye area $\left(\mathrm{cm}^{2}\right)$ & 18.40 & 18.61 & 19.73 & 20.55 & 20.23 & 0.86 & 0.3028 \\
\hline Yield of carcass $(\%)$ & 69.3 & 70.6 & 70.2 & 69.5 & 70.8 & 0.54 & 0.1803 \\
\hline Leaf fat weight ( $\mathrm{kg})$ & 1.52 & 1.70 & 1.52 & 1.49 & 1.56 & 0.10 & 0.6252 \\
\hline Percentage lean content of the carcasses (\%) & $48.0^{\mathrm{b}}$ & $47.9^{\mathrm{b}}$ & $51.5^{\mathrm{a}}$ & $50.2^{\mathrm{a}}$ & $51.5^{\mathrm{a}}$ & 0.65 & 0.0002 \\
\hline
\end{tabular}

a,b Different letters in same line mean significant difference $(\mathrm{P}<0.05)$.

Table 4. Effects of different conjugated linoleic acid (CLA) levels on the carcass parameters of pigs at $90 \mathrm{~kg}$.

\begin{tabular}{|c|c|c|c|c|c|c|c|}
\hline Items & Control & $0.5 \%$ CLA & $1 \%$ CLA & $1.5 \%$ CLA & $2 \%$ CLA & SE & P value \\
\hline Body weight at slaughter $(\mathrm{kg})$ & 90.9 & 90.3 & 89.6 & 89.9 & 89.8 & 1.17 & 0.9423 \\
\hline Vertical length $(\mathrm{cm})$ & 89.8 & 88.3 & 91.5 & 91.0 & 91.0 & 1.06 & 0.2124 \\
\hline Incline length $(\mathrm{cm})$ & 76.6 & 75.4 & 77.1 & 77.5 & 77.1 & 0.74 & 0.3064 \\
\hline \multicolumn{8}{|l|}{ Back fat depth $(\mathrm{cm})$} \\
\hline Shoulder-lumbar region & 3.52 & 3.35 & 3.05 & 3.09 & 3.03 & 0.15 & 0.0827 \\
\hline Between 6th and 7th ribs & $3.48^{\mathrm{a}}$ & $3.49^{\mathrm{a}}$ & $2.72^{\mathrm{c}}$ & $3.21^{\mathrm{ab}}$ & $2.93^{\mathrm{bc}}$ & 0.14 & 0.0009 \\
\hline \multicolumn{8}{|l|}{ Fat-skin depth (cm) } \\
\hline 10th rib & $3.58^{\mathrm{a}}$ & $3.58^{\mathrm{a}}$ & $2.83^{\mathrm{b}}$ & $3.00^{\mathrm{b}}$ & $2.83^{\mathrm{b}}$ & 0.17 & 0.0017 \\
\hline Last rib & 2.75 & 2.78 & 2.31 & 2.40 & 2.38 & 0.16 & 0.1407 \\
\hline Loin eye area $\left(\mathrm{cm}^{2}\right)$ & 22.46 & 22.45 & 24.19 & 24.92 & 24.91 & 0.87 & 0.1100 \\
\hline Yield of carcass $(\%)$ & $74.2^{\mathrm{a}}$ & $73.3^{\mathrm{ab}}$ & $71.8^{\mathrm{b}}$ & $72.7^{\mathrm{b}}$ & $72.5^{\mathrm{b}}$ & 0.50 & 0.0217 \\
\hline Leaf fat weight (kg) & $3.10^{\mathrm{a}}$ & $2.92^{\mathrm{ab}}$ & $2.52^{\mathrm{b}}$ & $2.60^{\mathrm{b}}$ & $2.48^{b}$ & 0.14 & 0.0131 \\
\hline Percentage lean content of the carcasses (\%) & $47.9^{\mathrm{b}}$ & $50.1^{\mathrm{ab}}$ & $52.5^{\mathrm{a}}$ & $50.4^{\mathrm{ab}}$ & $50.8^{\mathrm{a}}$ & 0.87 & 0.0157 \\
\hline
\end{tabular}

a,b,c Different letters in same line mean significant difference $(\mathrm{P}<0.05)$.

\section{Meat qualities}

The meat qualities of pigs at $60 \mathrm{~kg}$ are shown in Table 5 . We observed that 1.0, 1.5, and $2.0 \%$ CLA significantly reduced the $\mathrm{pH} 1$ value $(\mathrm{P}<0.01)$ by $4.53 \%(\mathrm{P}<0.05), 2.34 \%(\mathrm{P}>0.05)$, and $5.26 \%(\mathrm{P}<0.05)$, respectively, compared to that of the control. In addition, the $1.0 \%$ CLAfed pigs had a lower $\mathrm{b}^{*}$ value, and no significant difference was found among other treatments. Moreover, all CLA treatments significantly increased marble scaling by $10.82-32.47 \%$ compared with the control, and the $1.5 \%$ CLA-fed pigs exhibited the highest marble scaling $(\mathrm{P}<0.05)$.

\begin{tabular}{|c|c|c|c|c|c|c|c|}
\hline Items & Control & $0.5 \%$ CLA & $1 \%$ CLA & $1.5 \%$ CLA & $2 \%$ CLA & SE & P value \\
\hline $\mathrm{pH} 1$ & $6.84^{\mathrm{a}}$ & $6.94^{\mathrm{a}}$ & $6.53^{\mathrm{b}}$ & $6.68^{\mathrm{ab}}$ & $6.48^{b}$ & 0.10 & 0.0090 \\
\hline $\mathrm{pH} 2$ & 5.83 & 5.89 & 5.84 & 5.77 & 5.76 & 0.04 & 0.1596 \\
\hline Color & 3.75 & 3.75 & 3.75 & 3.75 & 3.56 & 0.09 & 0.4817 \\
\hline $\mathrm{L}^{*}$ & 34.7 & 34.8 & 33.9 & 35.6 & 34.6 & 0.75 & 0.6095 \\
\hline$a^{*}$ & 4.62 & 4.66 & 4.30 & 3.96 & 4.46 & 0.24 & 0.2364 \\
\hline $\mathrm{b}^{*}$ & $2.84^{\mathrm{a}}$ & $3.06^{\mathrm{a}}$ & $2.33^{\mathrm{b}}$ & $2.59^{\mathrm{ab}}$ & $2.74^{\mathrm{ab}}$ & 0.16 & 0.0335 \\
\hline Marbling & $2.31^{\mathrm{b}}$ & $2.75^{\mathrm{ab}}$ & $2.56^{\mathrm{ab}}$ & $3.06^{\mathrm{a}}$ & $2.63^{\mathrm{ab}}$ & 0.17 & 0.0456 \\
\hline Intramuscular fat (\%) & $1.72^{\mathrm{b}}$ & $2.49^{\mathrm{a}}$ & $2.62^{\mathrm{a}}$ & $2.49^{\mathrm{a}}$ & $2.50^{\mathrm{a}}$ & 0.20 & 0.0229 \\
\hline \multicolumn{8}{|l|}{ Shear force $(N)$} \\
\hline Semitendinosus & 4.34 & 4.37 & 4.89 & 5.31 & 4.84 & 0.28 & 0.1117 \\
\hline Psoas major & 2.12 & 2.58 & 2.40 & 2.60 & 2.75 & 0.21 & 0.3029 \\
\hline
\end{tabular}

$\overline{\mathrm{a}, \mathrm{b}}$ Different letters in same line mean significant difference $(\mathrm{P}<0.05)$. 
Table 6 shows the meat qualities of pigs at $90 \mathrm{~kg}$. We found that $0.5-2.0 \%$ CLA significantly decreased the $b^{*}$ value of meat by $7.61-15.96 \%$ compared to that of the control, and the $1.0 \%$ CLA-fed pigs had the lowest $b^{*}$ value $(\mathrm{P}<0.05)$. All CLA supplementations evidently increased marble scaling by $3.29-25.65 \%$ compared with the control, and the 1.5 and $2.0 \%$ CLA-fed pigs had higher marble scaling $(\mathrm{P}<0.01)$.

\begin{tabular}{|c|c|c|c|c|c|c|c|}
\hline Items & Control & $0.5 \%$ CLA & $1 \%$ CLA & $1.5 \%$ CLA & $2 \%$ CLA & SE & $P$ value \\
\hline$\overline{\mathrm{pH} 1}$ & 6.29 & 6.38 & 6.34 & 6.42 & 6.35 & 0.09 & 0.8955 \\
\hline PH2 & 5.38 & 5.42 & 5.43 & 5.37 & 5.33 & 0.05 & 0.6505 \\
\hline Color & 4.13 & 4.13 & 4.00 & 4.06 & 4.19 & 0.18 & 0.9575 \\
\hline $\mathrm{L}^{*}$ & 34.2 & 34.0 & 34.3 & 35.0 & 33.7 & 0.66 & 0.7291 \\
\hline$a^{*}$ & 4.49 & 4.50 & 4.29 & 4.68 & 5.12 & 0.28 & 0.3264 \\
\hline $\mathrm{b}^{*}$ & $2.89^{\mathrm{a}}$ & $2.66^{\mathrm{ab}}$ & $2.40^{\mathrm{b}}$ & $2.67^{\mathrm{ab}}$ & $2.55^{\mathrm{b}}$ & 0.10 & 0.0223 \\
\hline Marbling & $2.69^{\mathrm{b}}$ & $3.13^{\mathrm{ab}}$ & $2.94^{\mathrm{ab}}$ & $3.38^{\mathrm{a}}$ & $3.31^{\mathrm{a}}$ & 0.16 & 0.0239 \\
\hline Intramuscular fat (\%) & $2.19^{\mathrm{b}}$ & $3.21^{\mathrm{a}}$ & $2.93^{\mathrm{a}}$ & $3.10^{\mathrm{a}}$ & $3.08^{\mathrm{a}}$ & 0.22 & 0.0144 \\
\hline Water holding (\%) & 18.1 & 17.4 & 17.8 & 15.9 & 17.6 & 1.12 & 0.6647 \\
\hline Drip loss $(\%)$ & 2.02 & 2.11 & 1.78 & 1.70 & 1.98 & 0.14 & 0.2135 \\
\hline \multicolumn{8}{|l|}{ Shear force $(\mathrm{N})$} \\
\hline Semitendinosus & 4.36 & 4.47 & 4.50 & 4.77 & 4.55 & 0.28 & 0.8713 \\
\hline Psoas major & 3.58 & 3.10 & 2.90 & 3.11 & 3.15 & 0.21 & 0.2569 \\
\hline
\end{tabular}

a,b Different letters in same line mean significant difference $(\mathrm{P}<0.05)$.

\section{Changes in mRNA expression of regulators in the muscle fiber development}

Muscle fiber is an important structural unit of muscle, and differences in muscle fiber type significantly affect meat quality. As shown in Figure 1, compared with the control group of pigs at $60 \mathrm{~kg}$, all CLA-fed pigs exhibited higher expression of MyHC1 and MyHC2a, and the 1.5\% CLAfed pigs has the highest mRNA expression level $(\mathrm{P}<0.05)$. However, at $90 \mathrm{~kg}$, the highest expression level of both $\mathrm{MyHC1}$ and MyHC2a $(\mathrm{P}<0.05)$ was found in the 2.0\% CLA group (Figure 2). In addition, no significant changes in mRNA expression of MyHC2b and MyHC2x $(\mathrm{P}>0.05)$ were observed at $60 \mathrm{~kg}$, but the latter was downregulated in the $0.5 \%$ CLA-fed pigs at $90 \mathrm{~kg}$.
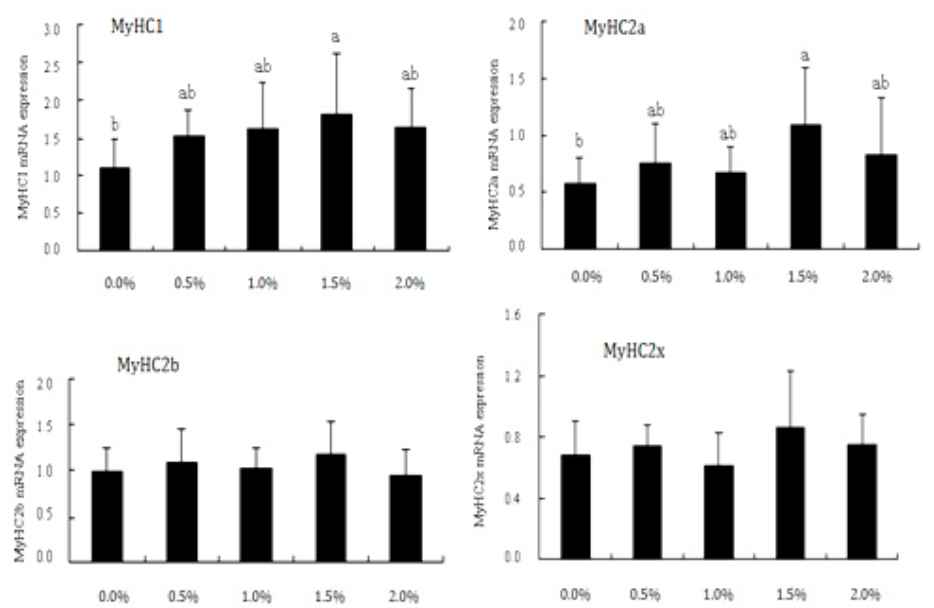

Figure 1. mRNA expression levels of regulators of muscle fiber development at $60 \mathrm{~kg}$ body weight. The mRNA levels were measured by real-time PCR analysis and normalized to $\beta$-actin. Values are reported as means $\pm \mathrm{SE}$; $\mathrm{N}=5$. Different letters on the bar mean $\mathrm{P}<0.05$. 

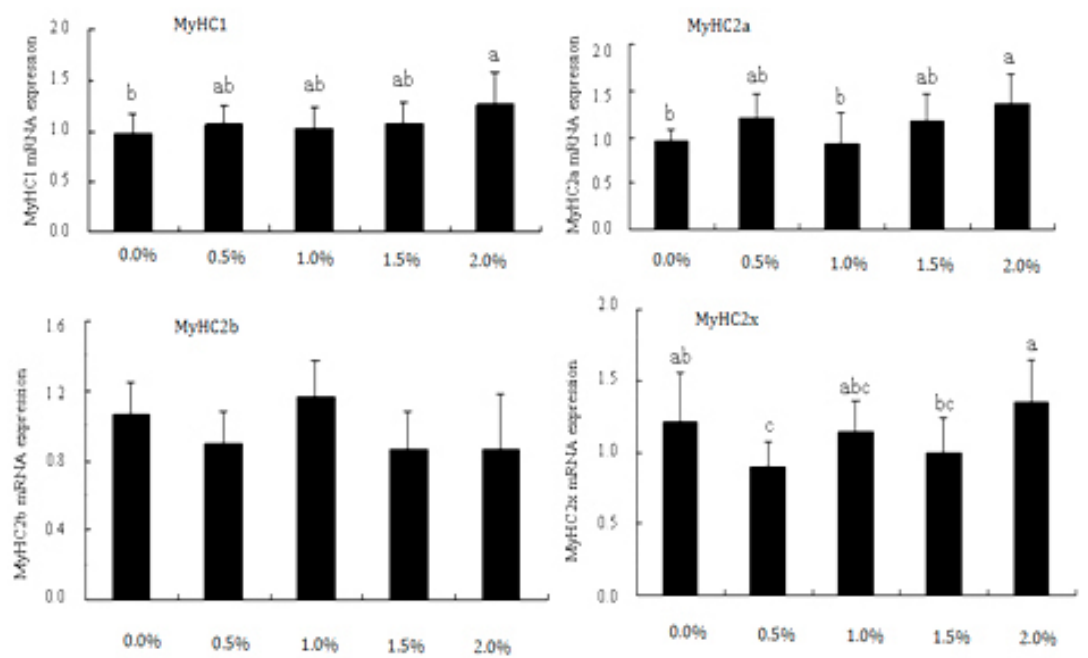

Figure 2. mRNA expression levels of regulators of muscle fiber development at $90 \mathrm{~kg}$ body weight. The mRNA levels were measured by real-time PCR analysis and normalized to $\beta$-actin. Values are reported as means \pm SE; N $=5$. Different letters on the bar mean $\mathrm{P}<0.05$.

\section{DISCUSSION}

Numerous studies have found that CLA significantly affects the growth, production, and health of animals (Decker, 1995; Pariza et al., 2000; De la Torre et al., 2005; Suksombat et al., 2006). Results from these studies suggested that CLA could inhibit the proliferation of tumor cells, reduce the occurrence of cardiovascular diseases, regulate the immune system and inflammatory responses, and decrease fat deposition via changes in the fat metabolism of animals. Therefore, CLA has been considered a beneficial nutritional additive for use in animal feeding.

In this study, we found that dietary CLA supplementation significantly affects the carcass traits of pig, especially fat deposition. Dietary CLA supplementation reduced fat deposition in some parts of the carcass, such as the back fat-depth in the shoulder-lumbar region. The percentage lean content of carcasses was higher in the CLA-fed pigs than in the control pigs, and the $1.0 \%$ CLA-fed pigs had the greatest value. An increasing body of evidence has proven that CLA serves a key function in the fat metabolism of animals (Azain et al., 2000; Miner et al., 2001; Hargrave-Barnes et al., 2008). Some experiments have shown that CLA decreased fat deposition by inhibiting adipocyte proliferation and differentiation (Ostrowska et al., 1999; Satory and Smith, 1999; Azain et al., 2000). In addition to fat deposition, CLA supplementation affects other indices of meat quality. In this study, the meat of CLA-fed pigs exhibited more IMF and marbling than control pigs. IMF content is an important determinant of meat quality and significantly affects other meat traits, such as tenderness, juiciness, flavor, and acceptability by consumers (Hovenier et al., 1993; Gao and Zhao, 2009; Barnes et al., 2012). Therefore, CLA supplementation to increase the percentage lean content of pig and increase the IMF of meat will improve meat quality and enhance the economic value of animal production.

We found that CLA supplementation changed the mRNA expression of some genes related to muscle fiber development and transformation. The growth and development of muscle fiber have important effects on meat quality. Several studies have found that the type and 
percentage of muscle fiber are importantly correlated with the color, $\mathrm{pH}$, drip loss, and IMF content of meat. However, a few studies on the CLA regulation of muscle fiber growth and development did not show a clear correlation.

In previous studies, the muscle fiber of pigs was categorized into 4 types depending on the myosin type, namely, MyHC1, MyHC2a, MyHC2b, and MyHC2x (Bottinelli and Reggiani, 2000). MyHC1 is an oxidized-type muscle fiber, whereas MyHC2a and 2b are glycolytic-type muscle fibers. Different types of muscle fibers should transform into one another as the pig grows (Berchtold et al., 2000). In this study, the expression of MyHC1, MyHC2a, and MyHC2x was evidently changed by CLA supplementation. However, the changes differed at the same times. The percentage increase of MyHC2a muscle fiber was considered to be beneficial for meat quality. However, $\mathrm{MyHC1}$ usually has higher expression in smaller pigs, and the reason why CLA supplementation upregulated $\mathrm{MyHC} 1$ expression remains unclear. However, we believe that appropriate CLA supplementation improves pig meat quality by indirectly affecting muscle fiber growth and development by altering gene expression.

In conclusion, dietary CLA supplementation decreased the back fat deposition, increased the lean content of the carcasses, and improved meat quality by modifying the mRNA expression of muscle fiber type genes in growing-finishing pigs. According to the study results, $1-1.5 \%$ CLA supplementation is appropriate.

\section{ACKNOWLEDGMENTS}

Research supported by the National Basic Research Program of China (Project \#2012CB124702, Beijing, China), the Development Program for 100 Outstanding Technological Leading Talents of Chongqing, and the Special Fund of Chongqing Key Laboratory (CSTC \#11308).

\section{REFERENCES}

Azain MJ, Hausman DB, Sisk MB, Flatt WP, et al. (2000). Dietary conjugated linoleic acid reduces rat adipose tissue cell size rather than cell number. J. Nutr. 130: 1548-1554.

Barnes KM, Winslow NR, Shelton AG, Hlusko KC, et al. (2012). Effect of dietary conjugated linoleic acid on marbling and intramuscular adipocytes in pork. J. Anim. Sci. 90: 1142-1149.

Belury MA (2002). Dietary conjugated linoleic acid in health: physiological effects and mechanisms of action. Annu. Rev. Nutr. 22: 505-531.

Berchtold MW, Brinkmeier H and Muntener M (2000). Calcium ion in skeletal muscle: its crucial role for muscle function, plasticity, and disease. Physiol. Rev. 80: 1215-1265.

Bottinelli R and Reggiani C (2000). Human skeletal muscle fibres: molecular and functional diversity. Prog. Biophys. Mol. Biol. 73: 195-262.

De la Torre A, Debiton E, Durand D, Chardigny JM, et al. (2005). Conjugated linoleic acid isomers and their conjugated derivatives inhibit growth of human cancer cell lines. Anticancer Res. 25: 3943-3949.

Decker EA (1995). The role of phenolics, conjugated linoleic acid, carnosine, and pyrroloquinoline quinone as nonessential dietary antioxidants. Nutr. Rev. 53: 49-58.

Gao SZ and Zhao SM (2009). Physiology, affecting factors and strategies for control of pig meat intramuscular fat. Recent Pat. Food Nutr. Agric. 1: 59-74.

Hargrave-Barnes KM, Azain MJ and Miner JL (2008). Conjugated linoleic acid-induced fat loss dependence on Delta6desaturase or cyclooxygenase. Obesity 16: 2245-2252.

Hayashi AA, de Medeiros SR, Carvalho MH and Lanna DP (2007). Conjugated linoleic acid (CLA) effects on pups growth, milk composition and lipogenic enzymes in lactating rats. J. Dairy Res. 74: 160-166. 
Hovenier R, Brascamp EW, Kanis E, van der Werf JH, et al. (1993). Economic values of optimum traits: the example of meat quality in pigs. J. Anim. Sci. 71: 1429-1433.

Joo ST, Lee JI, Ha YL and Park GB (2002). Effects of dietary conjugated linoleic acid on fatty acid composition, lipid oxidation, color, and water-holding capacity of pork loin. J. Anim. Sci. 80: 108-112.

Lu P, Li DF, Yin JD, Zhang LY, et al. (2008). Flavour differences of cooked longissimus muscle from Chinese indigenous pig breeds and hybrid pig breed (Duroc x Landrace x Large White). Food Chem. 107: 1529-1537.

Miner JL, Cederberg CA, Nielsen MK, Chen X, et al. (2001). Conjugated linoleic acid (CLA), body fat, and apoptosis. Obes. Res. 9: 129-134.

Ostrowska E, Muralitharan M, Cross RF, Bauman DE, et al. (1999). Dietary conjugated linoleic acids increase lean tissue and decrease fat deposition in growing pigs. J. Nutr. 129: 2037-2042.

Pariza MW, Park Y and Cook ME (2000). Mechanisms of action of conjugated linoleic acid: evidence and speculation. Proc. Soc. Exp. Biol. Med. 223: 8-13.

Qi RL, Sun C, Yang HL, Zhao X, et al. (2012). The molecular mechanism of fat accumulation changes in Black-Bone chickens with different energy intakes. J. Animal Feed Sci. 21: 361-371.

Satory DL and Smith SB (1999). Conjugated linoleic acid inhibits proliferation but stimulates lipid filling of murine 3T3L1 preadipocytes. J. Nutr. 129: 92-97.

Suksombat W, Samitayotin S and Lounglawan P (2006). Effects of conjugated linoleic acid supplementation in layer diet on fatty acid compositions of egg yolk and layer performances. Poult. Sci. 85: 1603-1609.

Thiel-Cooper RL, Parrish FC Jr, Sparks JC, Wiegand BR, et al. (2001). Conjugated linoleic acid changes swine performance and carcass composition. J. Anim. Sci. 79: 1821-1828.

Wang Q, Ji C, Huang J, Yang F, et al. (2011). The mRNA of lipin1 and its isoforms are differently expressed in the longissimus dorsi muscle of obese and lean pigs. Mol. Biol. Rep. 38: 319-325. 